\title{
Growth and accumulation of nutrients in papaya tree seedlings grown on organic substrates ${ }^{1}$
}

\author{
Francisca Evelice Cardoso de Souza ${ }^{*} \mathbb{D}$, William Natale ${ }^{2}$, Marilena de Melo Braga $^{3}$, \\ Rosilene Oliveira Mesquita ${ }^{2}$, Rafael Santiago da Costa ${ }^{2}$
}

$10.1590 / 0034-737 X 202168040003$

\begin{abstract}
The use of organic waste for the production of plant substrates is an important environmental and economic alternative. In this perspective, we performed a work in a greenhouse, with the aim of evaluating the effect of substrates from organic waste during growth, gas exchange and accumulation of mineral elements in 'Sunrise Solo' papaya tree seedlings. The experimental design adopted was completely randomized, with four treatments and five repetitions, with six plants in each repetition. The treatments consisted of four types of substrates, three from the composting of sewage sludge, green coconut shell and carnaubeira palm butt, and one was the Turfa Fértil ${ }^{\circledR}$ commercial. We evaluated biometric and physiological variables and accumulation of nutrients and heavy metals in papaya seedlings. The green coconut shell and carnaubeira palm butt substrates promoted superior results for growth, dry biomass, gas exchange and accumulation of nutrients, whereas the commercial substrate and sewage sludge produced seedlings of inferior quality considering all the analyzed variables.
\end{abstract}

Keywords: Carica papaya L.; dry biomass; gas exchange; mineral elements.

\section{INTRODUCTION}

Brazil has great prominence in the world fruit culture, being the third largest fruit producer and the twentieth largest exporter. Among the fruits cultivated in the country, the papaya (Carica papaya L.) deserves to be highlighted, being one of the most commercialized fruits in the supply centers. In 2018 alone, about one million tonnes of papaya were produced in Brazil (IBGE, 2020).

The papaya culture, as well as for several fruit species, involves the production of seedlings, which is one of the main phases for the economic exploitation of the species; therefore, special attention should be paid to this stage, which is mainly affected by the substrates used and their volume, since these factors can impair germination, entail malformation of the plants and their nutritional imbalance (Mesquita et al., 2012).

Currently, there are several commercial substrates available on the market, but they are expensive and their use represents an additional cost for the fruit grower. In view of this, alternative materials of low cost have been sought, which can compose new substrates, such as, for example, agricultural and industrial waste, where we can, with the use of these materials, reduce costs and produce seedlings with better quality (Oza et al., 2018), in addition to reducing the volume of waste discarded in the environment.

Accordingly, an alternative to using waste in the form of substrates for plants is its transformation into organic compost, through the composting process, since waste, when properly treated and used as organic compost, provides several nutrients and increases the water retention (Gomes \& Teinbrück, 2012), thereby bringing benefits to the environment.

In Brazil, there are several waste that have the potential to compose substrates, including the green coconut (Cocos nucifera) shell, the carnaubeira (Copernicia

\footnotetext{
Submitted on June $23^{\text {th }}, 2020$ and accepted on January $9^{\text {th }}, 2021$.

${ }^{1}$ This work is part of the first author's Master Dissertation.

${ }^{2}$ Universidade Federal do Ceará, Campus do Pici, Centro de Ciências Agrárias, Departamento de Fitotecnia, Fortaleza, Ceará, Brazil. evelicesouza@gmail.com; natale@ufc.br; rosilenemesquita@ufc.br; rafaelsantiagodacosta@yahoo.com.br

${ }^{3}$ Instituto Federal do Maranhão, Campus São Raimundo das Mangabeiras, São Raimundo das Mangabeiras, Maranhão, Brazil. marilena.braga@ ifma.edu.br

*Corresponding author: evelicesouza@gmail.com
} 
prunifera) palm butt and the sewage sludge. The use of coconut shell, especially when added to the soil, is a means of adding value to this waste, with its physicalchemical properties and low cost benefits of this material (Silva, 2014). The carnaubeira palm butt is the waste of the palm leaf, after the dust removal process (Favaro \& Miranda, 2013), being commonly used as mulch and substrate. Sewage sludge comes from sewage treatment and can be used in agriculture when composted (Heck et al., 2013).

In view of these aspects, this study aimed to evaluate the effect of substrates from organic waste during growth, gas exchange and accumulation of mineral elements in 'Sunrise Solo' papaya tree seedlings (Carica papaya L.).

\section{MATERIAL AND METHODS}

The experiment was carried out from January to February 2019, in a greenhouse of the Department of Phytotechnics, at Pici Campus, belonging to the Federal University of Ceará (UFC), located in Fortaleza - CE, with geographical coordinates: $3^{\circ} 44$ 'S latitude, $38^{\circ} 33^{\prime} \mathrm{W}$ longitude and 19.5 meters altitude.

For the formation of seedlings, four papaya seeds of the Solo group, Sunrise Solo variety, were sown at $1.5 \mathrm{~cm}$ deep, in black polyethylene bags, with dimensions of $12 \times$ $26 \mathrm{~cm}$ and a volume of $1 \mathrm{~L}$, filled with the substrates tested: sewage sludge compost, carnaubeira palm butt compost, green coconut shell compost and the Turfa Fértil® commercial substrate. At 21 days after sowing (DAS), thinning was accomplished, leaving two plants per bag; subsequently, 28 DAS was carried out the second thinning, leaving only one plant per container. We held irrigation manually twice a day, being conducted until the drainage of the water applied in each treatment was observed. The weeds were removed manually, as they appeared in the container.

The experimental design used was completely randomized (DIC), composed of four treatments and five repetitions, with six plants in each repetition, totaling 120 plants. The treatments consisted of four types of substrates: sewage sludge compost, carnaubeira palm butt compost, green coconut shell compost and the Turfa Fértil ${ }^{\circledR}$ commercial substrate.

For the production of composted substrates, each waste was mixed with laying chicken manure, in the proportion of $3: 1(\mathrm{v} / \mathrm{v})$; subsequently, the material was organized together with $50 \mathrm{~kg}$ of plaster in windrows layers $1 \mathrm{~m}$ high, $2 \mathrm{~m}$ wide and $2.5 \mathrm{~m}$ long. The windrows were revolved once a week to speed up the composting process for a period of seven months. After being ready, the compounds were crushed and sieved (Oliveira et al., 2005).

Rev. Ceres, Viçosa, v. 68, n.4, p. 267-275, jul/aug, 2021
Regarding the commercial substrate, we used Turfa Fértil@, whose raw materials are peat and carbonized rice husk. The sewage sludge was supplied in dry form by the sewage treatment plant (ETE) in Fortaleza, belonging to the Companhia de Água e Esgoto do Estado do Ceará (Cagece); the green coconut shell was donated by the Agroindústria Paraipaba company; the carnaubeira palm butt and the chicken manure were donated by Tijuca Alimentos.

The physical and chemical attributes of the substrates were determined following the methodology described by the Ministério da Agricultura, Pecuária e Abastecimento (Brazil, 2007), and the analyzes were carried out in the soil laboratory of Embrapa Agroindústria Tropical after the composting of the substrates. For the physical atributes, we evaluated: global density and water retention capacity (Table 1). As for chemical attributes, we determined water-soluble mineral elements (macronutrients, micronutrients and heavy metals), in addition to $\mathrm{pH}, \mathrm{EC}$ and CTC (Table 2).

In order to determine the effect of treatments on the production of papaya seedlings, at 42 DAS, we evaluated the following variables in all the 120 plants: plant height $(\mathrm{H})$, measured with a ruler graduated in millimeters, from the plant's neck to the last leaf insertion; stem diameter (DC), measured with a digital caliper on the plant's neck; as well as the number of leaves (NF), obtained by counting the fully developed leaves.

At 44 DAS, gas exchange evaluations were carried out between 9:00 and 12:00 h, using photosynthetically active radiation $\left(1200 \mu \mathrm{mol}\right.$ photons $\left.\mathrm{m}^{-2} \mathrm{~s}^{-1}\right)$, constant $\mathrm{CO}_{2}$ concentration (400 ppm), temperature and environment humidity, by means of an infrared gas analyzer (IRGA; portable model LI-6400XT, LI-COR Biosciences Inc., Lincon, Nebraska, USA). We determined the net photosynthetic rate (A), stomatal conductance $\left(\mathrm{g}_{\mathrm{s}}\right)$ and sweat rate (E). After such measurements, we calculated the instant water use efficiency (USA) and the instant carboxylation efficiency (A/Ci).

The collection of vegetative organs was done at 45 DAS, where the length of the main root was measured with a graduated ruler, and the leaf area was measured with a surface meter (LI - 3100, Area Meter, Li-Cor., Inc., Lincoln, 87 Nebraska, USA). Then, in order to determine the dry matter mass, the organs were washed in water with detergent, in a $30 \%$ hydrochloric acid solution and, finally, in deionized water; after that, the material was stored in paper bags and placed to dry in an oven with forced air circulation at $65^{\circ} \mathrm{C}$, until constant mass. Subsequently, the organs were weighed on a precision digital scale to obtain dry masses.

The total dry matter mass was also determined by adding the dry matter mass of the shoot and the roots, 
where we calculated the Dickson's quality index to estimate the seedling quality. The Dickson quality index (DQI) was calculated using the values of total dry matter mass (PMST), height $(\mathrm{H})$, stem diameter (DC), shoot dry matter mass (PMSPA) and root dry matter mass (PMSR) (Dickson et al., 1960), as displayed below:

$$
\mathrm{DQI}=\frac{\operatorname{PMST}(\mathrm{g})}{\frac{\mathrm{H}(\mathrm{cm})}{\mathrm{Dc}(\mathrm{mm})}+\frac{\operatorname{PMSA}(\mathrm{g})}{\operatorname{PMSR}(\mathrm{g})}}
$$

After obtaining the dry masses, the material was crushed in a basic analytical mill, submitted to nitroperchloric digestion and sent to Argon Plasma (ICP - OES) to determine the levels of $\mathrm{P}, \mathrm{K}, \mathrm{Ca}, \mathrm{Mg}, \mathrm{S}, \mathrm{Cu}, \mathrm{Fe}$,

Table 1: Global density (Dg) and water retention capacity (CRA) of substrates organic composted, Fortaleza-CE, 2019

\begin{tabular}{lcc}
\hline Substrato & Dg $\left(\mathbf{k g ~ m}^{-3}\right)$ & CRA(\%) \\
\hline Commercial & 326 & 64 \\
Green coconut shell & 638 & 55 \\
Carnaubeira palm butt & 627 & 53 \\
Sewage sludge & 645 & 52 \\
\hline
\end{tabular}

Dg - determined by the self-compacting method; CRA - determined with volumetric rings on a tension table.
Mn, Zn, Ni, Na, Al, As, Cd, Cr, Hg, Pb and Se (Silva, 2009). With the contents and dry matter content of the aerial part (PMSPA) and roots (PMSR), we calculated the accumulation (A). For the calculation of accumulation in the aerial part and in the roots, we used the expression: A $(\mathrm{mg})=$ PMSPA or PMSR $\times$ mineral element content. The total accumulation of elements in the plant was obtained by the sum of the values accumulated in the aerial part and in the roots. In this work, only the data related to the accumulation in the entire plant will be displayed.

The data were subjected to analysis of variance (ANOVA) and, when the test was significant at $5 \%$ or $1 \%$, the means comparison test was performed using the Tukey test, using the computer program Assistat 7.7 Beta.

\section{RESULTS}

The biometric variables plant height, stem diameter and number of leaves were significantly influenced by the applied treatments. The green coconut shell and carnaubeira palm butt substrates provided superior results for plant height (Figure 1A), stem diameter (Figure 1B) and number of leaves (Figure 1C) of papaya tree seedlings.

As for the variables on leaf area (Figure 2a), length of the main root (Figure 2b), dry matter mass of the shoot (Figure 3a), dry matter mass of the roots (Figure 3b), total

Table 2: Values of pH, CE, CTC and mineral elements of the substrates composted: commercial (C), green coconut shell (CC), carnaubeira palm butt (B) and sewage sludge (L), Fortaleza-CE, 2019

\begin{tabular}{|c|c|c|c|c|}
\hline \multirow{2}{*}{ Chemical element } & \multicolumn{4}{|c|}{ Substrate } \\
\hline & $\mathbf{C}$ & $\mathrm{CC}$ & B & $\mathbf{L}$ \\
\hline$\overline{\mathrm{pH}}$ & 5.5 & 6.7 & 6.4 & 6.4 \\
\hline $\mathrm{EC}\left(\mathrm{mS} \mathrm{cm}^{-1}\right)$ & 1.97 & 2.84 & 2.61 & 2.62 \\
\hline CTC $\left(\mathrm{mmol}_{\mathrm{c}} \mathrm{kg}^{-1}\right)$ & 870 & 201 & 225 & 210 \\
\hline $\mathrm{N}-\mathrm{NH}_{4}^{+}\left(\mathrm{g} \mathrm{L}^{-1}\right)$ & 0.024 & 0.024 & 0.024 & 0.019 \\
\hline $\mathrm{N}-\mathrm{NO}_{3}^{-}\left(\mathrm{g} \mathrm{L}^{-1}\right)$ & 0.096 & 0.043 & 0.053 & 0.058 \\
\hline $\mathrm{P}\left(\mathrm{g} \mathrm{L}^{-1}\right)$ & 0.001 & 0.027 & 0.052 & 0.024 \\
\hline $\mathrm{K}\left(\mathrm{g} \mathrm{L}^{-1}\right)$ & 0.058 & 0.142 & 0.162 & 0.163 \\
\hline $\mathrm{Ca}\left(\mathrm{g} \mathrm{L}^{-1}\right)$ & 1.737 & 2.566 & 2.469 & 1.850 \\
\hline $\operatorname{Mg}\left(g^{-1}\right)$ & 0.327 & 0.629 & 0.517 & 0.236 \\
\hline$S\left(\mathrm{~g} \mathrm{~L}^{-1}\right)$ & 1.277 & 1.931 & 1.777 & 1.275 \\
\hline $\mathrm{Na}\left(\mathrm{g} \mathrm{L}^{-1}\right)$ & 0.135 & 0.078 & 0.081 & 0.073 \\
\hline $\mathrm{Zn}\left(\mathrm{mg} \mathrm{L}^{-1}\right)$ & 0 & 0 & 0 & 4.90 \\
\hline $\mathrm{Fe}\left(\mathrm{mg} \mathrm{L}^{-1}\right)$ & 1.4 & 0.15 & 0.20 & 0.50 \\
\hline $\operatorname{Mn}\left(\mathrm{mg} \mathrm{L}^{-1}\right)$ & 3.05 & 1.10 & 2.35 & 1.35 \\
\hline $\mathrm{Cu}\left(\mathrm{mg} \mathrm{L}^{-1}\right)$ & 0.05 & 0.10 & 0.10 & 0.95 \\
\hline $\mathrm{Al}\left(\mathrm{mg} \mathrm{L}^{-1}\right)$ & 1.00 & 0.70 & 1.10 & 1.05 \\
\hline $\mathrm{Ni}\left(\mathrm{mg} \mathrm{L}^{-1}\right)$ & 0 & 0.05 & 0 & 7.30 \\
\hline As $\left(\mathrm{mg} \mathrm{L}^{-1}\right)$ & 0 & 0 & 0 & 0 \\
\hline $\mathrm{Cd}\left(\mathrm{mg} \mathrm{L}^{-1}\right)$ & 0 & 0 & 0 & 0 \\
\hline $\mathrm{Cr}\left(\mathrm{mg} \mathrm{L}^{-1}\right)$ & 0.05 & 0.05 & 0.05 & 0.05 \\
\hline $\mathrm{Hg}\left(\mathrm{mg} \mathrm{L}^{-1}\right)$ & 0 & 0.05 & 0 & 0 \\
\hline $\mathrm{Pb}\left(\mathrm{mg} \mathrm{L}^{-1}\right)$ & 0 & 0 & 0 & 0 \\
\hline $\operatorname{Se}\left(\mathrm{mg} \mathrm{L}^{-1}\right)$ & 0 & 0 & 0 & 0.15 \\
\hline
\end{tabular}

Extracted by the water-soluble nutrient method; $\mathrm{pH}$ in water 1:5; EC - electrical conductivity; CTC - cation exchange capacity. 
dry matter mass (Figure 3c) and Dickson Quality Index (Figure 4), all showed superior results when papaya tree seedlings were grown on the green coconut shell and carnaubeira palm butt substrates.

Regarding the gas exchange analysis of papaya tree seedlings, we found that only the variables photosynthesis (A) and instantaneous efficiency of water use (USA) showed significant responses depending on the applied treatments. When the seedlings were grown with green coconut shell and carnaubeira palm butt, there was a superior result for photosynthesis (Figure 5a) and for the instant efficiency of water use (Figure 5b).

When analyzing the accumulation of nutrients, we found that all determined macronutrients, in addition to the sodium, were significantly influenced by the applied treatments. As for micronutrients, only iron did not suffer a significant effect from the treatments. The carnaubeira palm butt provided the best results with higher accumulation for all elements, except for $\mathrm{Ni}$, while the commercial substrate promoted lower accumulation for macronutrients, micronutrients and the sodium (Table 3).

For the accumulation of heavy metals, we found that all the evaluated elements had significant responses (Table 4). In the tissue analysis of the seedlings, $\mathrm{As}, \mathrm{Cd}$ and $\mathrm{Hg}$ were not detected, which, however, does not signalize the absence of these metals in the plant tissue, which may be present in quantities below the detection limit of the argon plasma. The failure in identifying these heavy metals by the methods used made it impossible to quantify their accumulation in plant tissues.


Figure 1: Height (A), stem diameter (B) and number of leaves (C) of papaya tree seedlings grown on commercial substrates (C), carnaubeira palm butt (B), green coconut shell (CC) and sludge sewage (L), Fortaleza - CE, 2019.

A

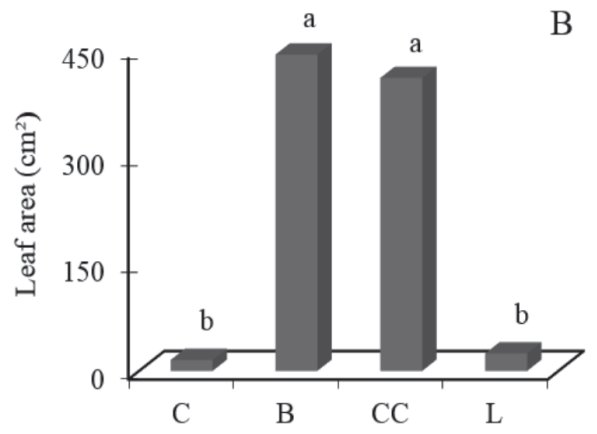

B

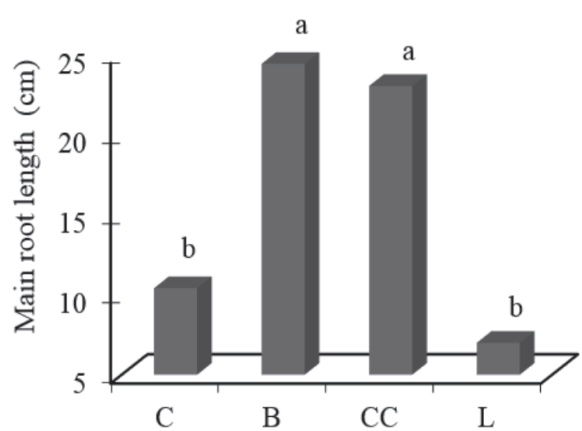

Figure 2: Leaf area (A) and main root length (B) of papaya tree seedlings grown on commercial substrates (C), carnaubeira palm butt (B), green coconut shell (CC) and sewage sludge (L), Fortaleza - CE, 2019. 


\section{DISCUSSION}

Only seedlings grown with carnaubeira palm butt and green coconut shell showed recommended height for planting in the field, since according to literature recommendations, papaya tree must be transplanted to a definitive location when it reaches 15 to $20 \mathrm{~cm}$ in height (Chaves et al., 2000). The higher height of the seedlings is the result of the greater supply of nutrients from these substrates, especially calcium (Table 2). The effect of Ca on plant height growth stems from its function in plant metabolism, since this nutrient participates in cell division and elongation, in addition to playing a structural role, participating in the composition of the cell membrane and providing resistance to the cell wall primary (Barker \& Pilbeam, 2015).

The stem diameter followed the same trend as the height, signalizing that the seedlings did not undergo stiolation, since the growth in height was accompanied by the development of the stem. Plants with a high stem diameter tend to excel in the field, due to their greater vigor (Diniz et al., 2018). This result corroborates the study by Albano et al. (2017), where the highest values of height and diameter of the stem of papaya tree seedlings were obtained from the substrates of semidecomposed carnaubeira palm tree and earthworm humus, with the largest stem diameter being related to the height of the plant, due to the accumulation of photoassimilates.

For the number of leaves, we found that the difference of more than $100 \%$ between the quantity of leaves of the

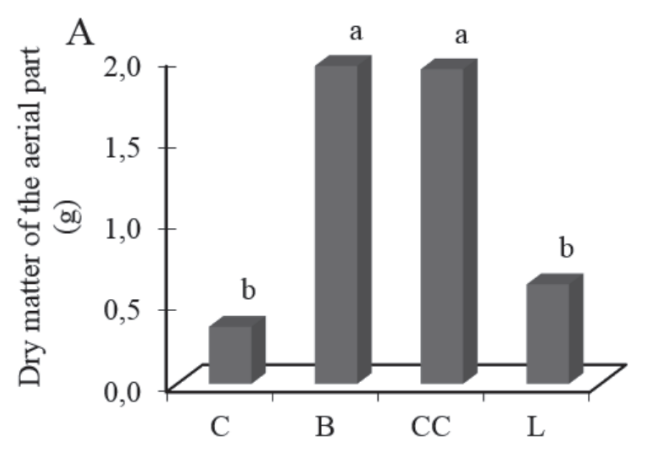

plants of the commercial substrate and of the seedlings of the green coconut shell substrate can be attributed to the lower supply of nutrients from the commercial substrate, which showed, in general, the lowest concentrations of nutrients among the tested substrates. The positive effect of carnaubeira palm butt and green coconut shell on leaf emission in seedlings is due to the higher concentration of macronutrients in these treatments (Table 2), since plant growth variables are related to higher concentrations of K, Ca and Mg (Melo et al., 2019).

The lower input of macronutrients from the commercial substrate and from the sewage sludge promoted both the reduced leaf emission in the plants of these treatments, as well as provided the decreased development of the leaf area of the seedlings. This situation was also observed by Nomura et al. (2008), where the substrate that promoted

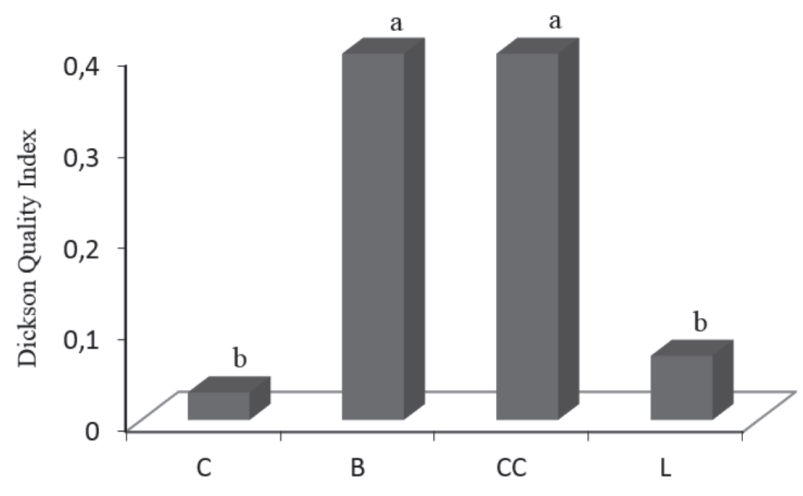

Figure 4: Dickson Quality Index of papaya tree seedlings, grown on different substrates, Fortaleza - CE, 2019.

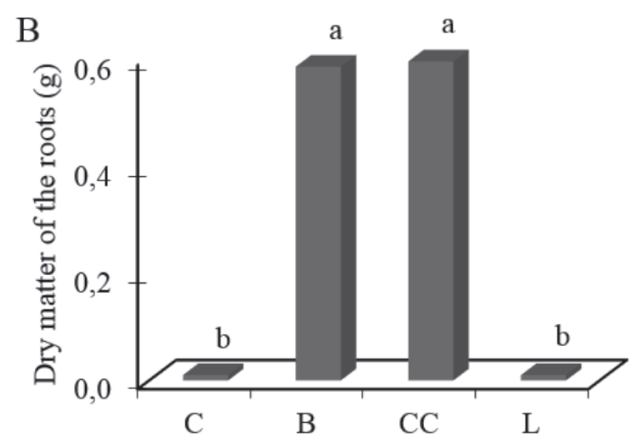

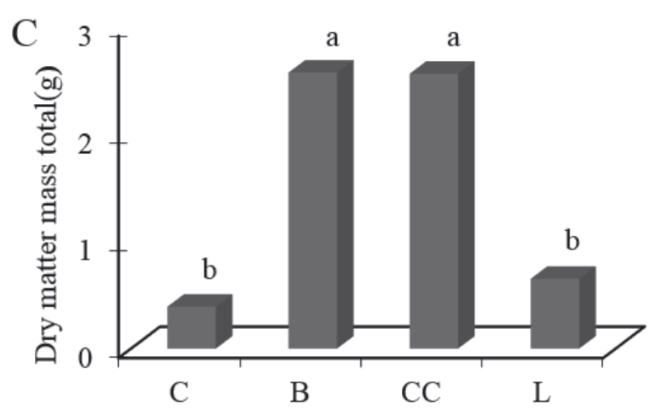

Figure 3: Mass of dry matter of the aerial part (A), mass of dry matter of the roots (B) and total dry matter mass (C) of papaya tree seedlings grown on commercial substrates (C), carnaubeira palm butt (B), green coconut shell (CC) and sewage sludge (L), Fortaleza - CE, 2019. 
the smallest leaf area and the growth of banana tree seedlings typified as Nanicão showed the lowest concentrations of N, S, Ca and Mg. Such results show that, for adequate plant nutrition, it is necessary that all nutrients are available in adequate quantities.

The growth of the root system of plants is affected by the physical and chemical characteristics of the substrates; however, in this experiment, the physical variable global density (Table 1) did not affect root growth. According to Petry (1999), the ideal substrate density for growing agricultural species in plastic containers is between 350 and $500 \mathrm{~kg} \mathrm{~m}^{-3}$. Therefore, the density values of the tested substrates are outside this classification; however, as this variable did not affect root growth, it is concluded that the ideal density varies depending on the plant species grown.

The chemical attribute that most influenced the growth of the roots was the nutritional composition of the substrates, since the carnaubeira palm butt and the

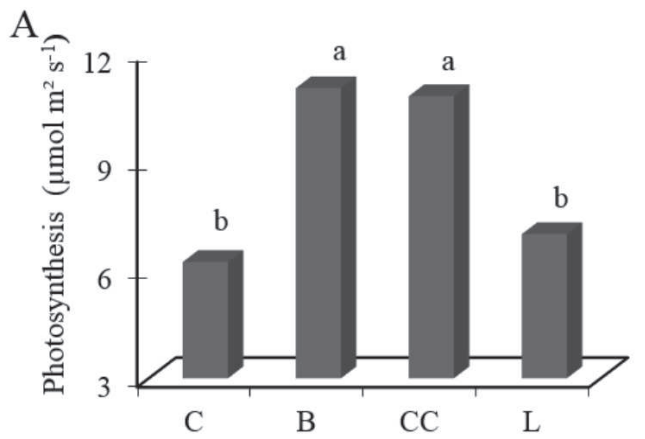

coconut shell showed the highest concentrations of phosphorus, which stimulates root growth. Although $\mathrm{P}$ is the macronutrient required in the least amount by papaya tree, this element is of great importance in the root growth phase (Oliveira et al., 2009), since it stimulates the production of plant biomass (Dias et al., 2009). Nevertheless, P deficiency causes damage to plant growth, due to the lower production of roots and shoots (Saraiva et al., 2011), a fact observed in the commercial substrate and sludge seedlings.

The greater volume of root dry matter of seedlings grown with carnaubeira palm butt and green coconut shell was accompanied by the production of dry matter from the shoot. This fact results from well-developed roots, which promotes greater absorption of water and nutrients, boosts plant growth and produces good quality seedlings. Adequate nutrition promotes the growth of the aerial part and promotes better development of the roots, thereby benefiting the exploration of larger volumes of substrate

B

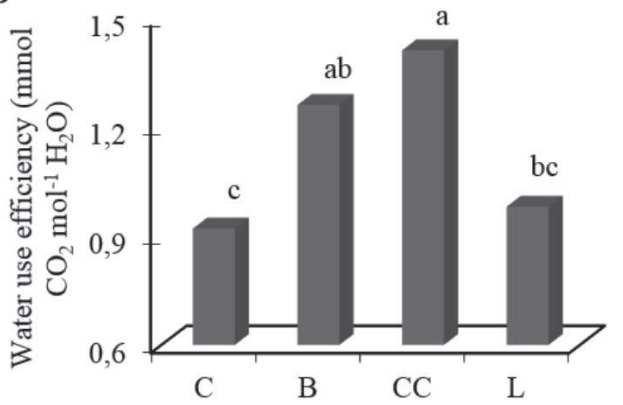

Figure 5: Photosynthesis (A) and water use efficiency (B) of papaya tree seedlings, grown on commercial substrates (C), carnaubeira palm butt (B), green coconut shell (CC) and sewage sludge (L), Fortaleza - CE, 2019.

Table 3: Average values of accumulation of macronutrients, sodium element and micronutrients in the whole plant of papaya tree seedlings grown on commercial substrates (C), carnaubeira palm butt (B), green coconut shell (CC) and sewage sludge (L), FortalezaCE, 2019

\begin{tabular}{|c|c|c|c|c|c|c|c|c|c|c|}
\hline \multirow{2}{*}{ Substrate } & $\mathbf{P}$ & $\mathbf{K}$ & Ca & $\mathbf{M g}$ & $\mathbf{S}$ & $\mathrm{Na}$ & $\mathbf{Z n}$ & Mn & $\mathrm{Cu}$ & $\mathrm{Ni}$ \\
\hline & \multicolumn{10}{|c|}{$\left(\mathrm{mg} \mathrm{plant}^{-1}\right)$} \\
\hline $\bar{C}$ & $0.7 \mathrm{~d}$ & $6 \mathrm{~b}$ & $10 \mathrm{c}$ & $8.0 \mathrm{~b}$ & $4.2 \mathrm{~b}$ & $1.8 \mathrm{c}$ & $21 \mathrm{c}$ & $62 c$ & $6 \mathrm{~b}$ & $1 \mathrm{~b}$ \\
\hline B & $13.3 \mathrm{a}$ & $84 \mathrm{a}$ & $47 \mathrm{a}$ & $30.7 \mathrm{a}$ & $14.5 \mathrm{a}$ & $7.4 \mathrm{a}$ & $226 \mathrm{a}$ & $148 \mathrm{a}$ & $33 \mathrm{a}$ & $13 \mathrm{~b}$ \\
\hline $\mathrm{CC}$ & $9.9 \mathrm{~b}$ & $75 \mathrm{a}$ & $33 \mathrm{~b}$ & $27.8 \mathrm{a}$ & $12.7 \mathrm{a}$ & $5.2 \mathrm{~b}$ & $176 \mathrm{ab}$ & $106 \mathrm{~b}$ & $45 \mathrm{a}$ & $14 \mathrm{~b}$ \\
\hline $\mathrm{L}$ & $3.2 \mathrm{c}$ & $14 \mathrm{~b}$ & $20 \mathrm{c}$ & $5.9 \mathrm{~b}$ & $6.0 \mathrm{~b}$ & $3.5 \mathrm{bc}$ & $137 \mathrm{~b}$ & $38 \mathrm{c}$ & $28 \mathrm{a}$ & $101 \mathrm{a}$ \\
\hline
\end{tabular}

Means followed by the same letter in each column do not differ by Tukey test.

Table 4: Average values of accumulation of heavy metals in the whole plant of papaya tree seedlings grown on commercial substrates (C), carnaubeira palm butt (B), green coconut shell (CC) and sewage sludge (L), Fortaleza - CE, 2019

\begin{tabular}{lrrrr}
\hline \multirow{2}{*}{ Substrate } & Al & Cr & Pb & S e \\
\cline { 2 - 5 } & & \multicolumn{2}{c}{ (mg plant $\left.^{-1}\right)$} & \\
\hline C & $147 \mathrm{~b}$ & $1.9 \mathrm{~b}$ & $0.8 \mathrm{c}$ & $0.03 \mathrm{~b}$ \\
$\mathrm{~B}$ & $1156 \mathrm{a}$ & $23.0 \mathrm{a}$ & $18.4 \mathrm{a}$ & $0.0 \mathrm{~b}$ \\
$\mathrm{CC}$ & $1154 \mathrm{a}$ & $20.6 \mathrm{a}$ & $11.0 \mathrm{~b}$ & $2.89 \mathrm{~b}$ \\
$\mathrm{~L}$ & $320 \mathrm{~b}$ & $5.6 \mathrm{~b}$ & $1.5 \mathrm{c}$ & $2.3 \mathrm{a}$ \\
\hline
\end{tabular}

Means followed by the same letter in each column do not differ by Tukey test.

Rev. Ceres, Viçosa, v. 68, n.4, p. 267-275, jul/aug, 2021 
and stimulating greater absorption of water and essential elements (Natale et al., 2018).

The higher concentration of macronutrients in the carnaubeira palm butt and in the coconut shell provided the superior growth of the plants, which became a greater production of total dry matter. This result corroborates that of Melo et al. (2019), where the authors observed that the highest values of dry biomass, leaf area and root length of guabiroba plants were related to the highest concentrations of $\mathrm{Ca}$ and $\mathrm{Mg}$ in the substrate and, also, with the highest availability of N, P, K and S by increasing the $\mathrm{pH}$. In this study, the $\mathrm{pH}$ values of the tested substrates are within the appropriate range for the papaya tree culture, which is 5.5 to 6.7 (Oliveira et al., 2009), thereby not affecting the availability of nutrients.

The negative results of the commercial substrate and the sewage sludge on the biometric variables of the seedlings can be explained by the chemical composition of these treatments, which, in general, showed the lowest values of macronutrients and highest values of micronutrients. Micronutrients, although essential to plants, taking part in metabolic processes and acting as an enzymatic cofactor (Oliveira \& Silva, 2016) are required in small amounts and can, therefore, easily take place in toxic concentrations that harm plants and delay plant growth (Alexandre et al., 2012).

As for the quality of seedlings, only plants grown with carnaubeira palm butt and green coconut shell showed Dickson quality index above the recommended minimum value, which is 0.20 (Hunt, 1990). These higher quality seedlings have a greater chance of survival in the orchard, besides optimizing production systems due to their shorter formation time, since the seedlings in only 45 DAS were suitable for planting in the field. This situation increases the quantity of seedlings produced during the year due to the shorter time spent in the nursery, which increases the productivity of the production systems.

With respect to gas exchange, we found that, although papaya tree seedlings had the same chronological age in all periods of evaluation, they showed very different growth, which suggests that the plants were in different stages at the end of the experiment. This fact affects gas exchange, as the growth of the leaves increases the photosynthetic activity and the capacity of plants to produce photosynthesis (Silva et al., 2013). The leaves start their development as drains and, when they reach 40 to $50 \%$ of the final size, they change state, thereby assuming the function of source (Taiz et al., 2017).

The good nutritional composition of the green coconut shell and the carnaubeira palm butt provided the greatest growth of the plants, which fostered the faster development of the leaves of the seedlings in these treatments, thereby increasing their photosynthetic rate and transforming them into source organs. This increase in photosynthesis is linked to episodes such as leaf development, increased leaf area and photosynthetic pigments (Campostrini et al., 2001). As for the seedlings of commercial substrates and sewage sludge, their lower photosynthetic rates result from their leaf immaturity, since new and expanding leaves do not have the fully developed photosynthetic apparatus (Dantas et al,. 2007).

Similar to what happened for the photosynthetic rate, the seedlings of the substrates green coconut shell and the carnaubeira palm butt were the most efficient in the use of water, which signalizes that more $\mathrm{CO}_{2}$ was assimilated by these plants with less water loss (Silva et al., 2013), while the commercial substrate and sewage sludge seedlings showed less momentary efficiency in water use.

When evaluating the accumulation of macronutrients in papaya tree plants, we found that this was generally related to the highest concentrations of these nutrients in the carnaubeira palm butt and in the coconut shell, which provided the best accumulation results. Combined with the good nutritional composition of these substrates, another factor that contributed to the greater accumulation was the high production of biomass from seedlings in these treatments, since there is a parallel between the production of dry matter and the accumulation of nutrients in vegetables (Malavolta, 2006) and that the accumulation is the product of the dry mass by the nutrient content in the plant.

The accumulation of macronutrients in the seedlings took place in the following sequence: $\mathrm{K}>\mathrm{Ca}>\mathrm{Mg}>\mathrm{S}>\mathrm{P}$. This result corroborates that observed by Oliveira et al. (2009) for the absorption of macronutrients by the shoot of adult papaya tree plants in the first year of cultivation, which took place in the following decreasing sequence: $\mathrm{K}, \mathrm{N}, \mathrm{Ca}, \mathrm{Mg}, \mathrm{S}$ and P. In this study, it was not possible to analyze $\mathrm{N}$ due to the reduced biomass production of plants in the commercial substrate. Such results suggest that the accumulation of macronutrients by papaya plants in the seedling phase follows the same sequence of absorption of the plants in the adult phase.

As for the accumulation of micronutrients and the sodium element in the seedlings, we noticed that there was a greater relationship with the production of dry matter in plants than with the concentration of these elements in the substrates. Although $\mathrm{Zn}$ was detected only in sewage sludge and $\mathrm{Ni}$ in green coconut shell and sewage sludge, these metals accumulated in the tissues of all seedlings. This may be due to the mineralization of these elements during the experiment, or the fact that only water-soluble nutrients were quantified in the substrates, which suggests that plants can absorb a greater fraction of elements than only those soluble in water. 
Although the seedlings of the sewage sludge substrate had reduced biomass production, there was a higher accumulation of nickel in the plants, which suggests a possible excess of this metal in the plants cultivated with sludge. The excess of Ni negatively affects the growth of plants, because, when present in high values in plant tissue, nickel inhibits processes such as respiration and photosynthesis, thereby causing disturbances in the Calvin-Benson cycle, in addition to affecting the absorption of other nutrients when present in high concentrations in the substrate (Torres et al., 2016).

The accumulation of micronutrients in papaya tree seedlings was, in general, similar to the results of mass production of dry matter, except for copper and nickel, which had higher accumulation in seedlings cultivated with sewage sludge, and the plants accumulated the micronutrients in the following sequence: $\mathrm{Fe}>\mathrm{Zn}>\mathrm{Mn}>$ $\mathrm{Ni}>\mathrm{Cu}$. This result corroborates the work of Mesquita et al. (2010) regarding the leaf contents of adult papaya tree (little) plants from Santa Amália under different biofertilizers.

Regarding the accumulation of heavy metals in papaya tree seedlings, this was influenced by the dry matter production of the plants, since the seedlings cultivated with carnaubeira palm butt and green coconut shell, which produced greater dry biomass, showed, in general, higher accumulation of these elements, with the exception of selenium, which had a superior result in plants grown with sewage sludge.

Although there was a significant accumulation of aluminum in the seedlings grown with carnaubeira palm butt and green coconut shell, there were no symptoms of toxicity in the plants of these treatments, which manifest themselves primarily in the roots with reduced growth of the main axis and inhibition of the formation of the lateral roots (Malavolta, 2006). During the experiment, no toxicity symptoms were observed in the plants of any of the tested treatments.

The concentration of heavy metals in sewage sludge is below the maximum limit considered appropriate by Resolution $n^{\circ} 375 / 2006$ of the Conselho Nacional do Meio Ambiente, which ensures that this waste can be safely used in agriculture without causing damage to the environment (Brazil, 2006). Nevertheless, the higher values of heavy metals and micronutrients in the sewage sludge, in comparison to the other substrates, impaired the growth of the plants, thereby resulting in low quality papaya tree seedlings and with higher accumulation of the following elements: $\mathrm{Cu}, \mathrm{Ni}$ and $\mathrm{Se}$.

In view of these aspects, an alternative to mitigate the highest concentrations of micronutrients and heavy metals in the sewage sludge is the use of smaller containers, which reduces the volume of substrate in contact with the plant, or, the use of this waste in lower proportion in the substrate, as checked by Siqueira et al. (2019), where the lowest proportion of sewage sludge was adequate for the production of vineyard seedlings (Plathymenia reticulata).

\section{CONCLUSIONS}

The substrates made of carnaubeira palm butt and green coconut shell proved to be the most efficient for the production of papaya tree seedlings in polyethylene bags, as these waste produced seedlings with superior biometric and physiological variables, in addition to providing an adequate supply of nutrients.

The commercial substrate and the sewage sludge produced seedlings of inferior quality, with low growth and reduced accumulation of nutrients, thereby not being indicated for the production of papaya tree seedlings under the conditions in which this study was held.

\section{ACKNOWLEDGEMENTS, FINANCIAL SUPPORT AND FULL DISCLOSURE}

The authors wish to thank to the Conselho Nacional de Desenvolvimento Científico e Tecnológico (CNPQ), for granting the scholarship, to Embrapa Agroindústria Tropical, especially the Soil Laboratory, for making facilities available, the companies Agroindústria Paraipaba, Tijuca Alimentos e Companhia de Água e Esgoto do Estado do Ceará (Cagece), for the donation of organic waste for the production of substrates.

The authors declare there to be no conflict of interest in carrying out or publishing this work.

\section{REFERENCES}

Albano FG, Cavalcante ÍHL, Machado JS, Lacerda CF, Silva ER \& Sousa HG (2017) New substrate containing agroindustrial carnauba residue for production of papaya under foliar fertilization. Revista Brasileira de Engenharia Agrícola e Ambiental, 21:128-133.

Alexandre JR, Oliveira MLF, Santos TC, Canton GC, Conceição JM, Eutrópio FJ, Cruz ZMA, Dobbss LB \& Ramos AC (2012) Zinco e ferro: de micronutrientes a contaminantes do solo. Natureza on line, 10:23-28.

Barker AV \& Pilbeam DJ (2015) Handbook of plant nutrition. $2^{\text {nd }}$ ed. London, CRC Press. 662p.

Brazil (2006) Resolução Conama n ${ }^{\circ}$ 12, de 29 de agosto de 2006. Define critérios e procedimentos, para o uso agrícola de lodos de esgoto gerados em estações de tratamento de esgoto sanitário e seus produtos derivados, e dá outras providências. DOU, 30/08/2006, Section 3, p.6.

Brazil (2007) Instrução Normativa ${ }^{\circ} 17$, de 21 de maio de 2007. Aprova os Métodos Analíticos Oficiais para Análise de Substratos e Condicionadores de Solos. DOU, 24/02/2007, Section 1, p.8.

Campostrini E, Yamanishi OK \& Martinez CA (2001) Leaf gas exchange characteristics of four papaya genotypes during different stages of development. Revista Brasileira de Fruticultura, 23:522-525. 
Chaves JCM, Cavalcanti Junior AT, Correia D, Souza FX \& Araújo CAT (2000) Normas de produção de mudas. Fortaleza, Embrapa Agroindústria Tropical. $37 \mathrm{p}$.

Dantas BF, Ribeiro LS \& Pereira MS (2007) Teor de açúcares solúveis e insolúveis em folhe de videiras, cv. syrah, em diferentes posições no ramo e épocas do ano. Revista Brasileira de Fruticultura, 29:42-47.

Dias TJ, Pereira WE, Cavalcante LF, Raposo RWC \& Freire JLO (2009) Desenvolvimento e qualidade nutricional de mudas de mangabeiras cultivadas em substratos contendo fibra de coco e adubação fosfatada. Revista Brasileira de Fruticultura, 31:512523

Dickson A, Leaf AL \& Hosner JF (1960) Quality appraisal of white spruce and white pine seedling stock in nurseries. The Forestry Chronicle, 36:10-13.

Diniz GL, Sales GN, Sousa VFO, Andrade FHA, Silva SS \& Nobre RG (2018) Produção de mudas de mamoeiro sob salinidade da água irrigação e adubação fosfatada. Revista de Ciências Agrárias, 41:218-228.

Favaro SP \& Miranda CHB (2013) Aproveitamento de espécies nativas e seus coprodutos no contexto de biorrefinaria. Brasília, Embrapa Agroenergia. 87p.

Gomes ER \& Steinbrück MA (2012) Oportunidades e dilemas do tratamento dos resíduos sólidos no Brasil à luz da política nacional de resíduos sólidos (Lei N. 12.305/2010). Confluências Revista Interdisciplinar de Sociologia e Direito, 14:100-114.

Heck K, Marco ÉG, Hahn ABB, Kluge M, Spilki FR \& Sand STVD (2013) Temperatura de degradação de resíduos em processo de compostagem e qualidade microbiológica do composto final. Revista Brasileira de Engenharia Agrícola e Ambiental, 17:54-59.

Hunt GA (1990) Effect of styroblock design and copper treatment on morphology of conifer seedlings. In: Rose R, Campbell SJ \& Landis TD (Eds) Proceedings of Target Seedling Symposium, Meeting of the Western Forest Nursery Associations. Fort Collins, USDA Forest Service. p.218-222.

IBGE - Instituto Brasileiro de Geografia e Estatística (2020) Produção Agrícola Municipal: Lavoura permanente. Available at: <https://sidra.ibge.gov.br/tabela/5457\#resultado> Accessed on: March $12^{\text {th }}, 2020$.

Malavolta E (2006) Manual de nutrição mineral de plantas. $2^{\text {nd }}$ ed. São Paulo, Agronômica Ceres. 638p.

Melo RM, Vieira MC, Carnevali TO, Gonçalves WV, Torales EP, Tolouei SEL \& Santos CC (2019) Calagem e textura do substrato afetam o desenvolvimento de Campomanesia adamantium (Cambess.) O. Berg. Revista de Ciências Agrárias, 42:101-110.

Mesquita EF, Cavalcante LF, Gondim SC, Campos VB, Cavalcante ÍHL \& Gondim PC (2010) Teores foliares e exportação de nutrientes do mamoeiro baixinho de Santa Amália tratado com biofertilizantes. Pesquisa Agropecuária Tropical, 40:66-76.

Mesquita EF, Chaves LHG, Freitas BV, Silva GA, Sousa MVR \& Andrade R (2012) Produção de mudas de mamoeiro em função de substratos contendo esterco bovino e volumes de recipientes. Revista Brasileira de Ciências Agrárias, 7:58-65.
Natale W, Lima Neto AJ, Rozane DE, Parent LE \& Corrêa MCM (2018) Mineral nutrition evolution in the formation of fruit tree rootstocks and seedlings. Revista Brasileira de Fruticultura, 40:1-15.

Nomura ES, Lima JD, Garcia VA \& Rodrigues DS (2008) Crescimento de mudas micropropagadas da bananeira cv. Nanicão, em diferentes substratos e fontes de fertilizante. Acta Scientiarum Agronomy, 30:359-363.

Oliveira AMG, Aquino AM \& Castro Neto MT (2005) Compostagem caseira de lixo orgânico doméstico. Cruz das Almas, Embrapa Mandioca e Fruticultura Tropical. 6p. (Circular Técnica, 76).

Oliveira AMG, Souza LFS \& Coelho EF (2009) Mamoeiro. In: Crisóstomo LA \& Naumov A (Orgs.) Adubando para alta produtividade e qualidade: fruteiras tropicais do Brasil. Fortaleza, Embrapa Agroindústria Tropical. p.146-163.

Oliveira ID \& Silva J (2016) Crescimento e desenvolvimento de plântulas de alface (Lactuca sativa L.) oriundas de sementes recobertas com" ferti-peixe". South American Journal of Basic Education, Technical and Technological, 3:110-117.

Oza EF, Monaco PAVL, Santos MM, Rosado TL, Krause MR \& Garcia WA (2018) Aproveitamento de escória de siderurgia em substratos alternativos para produção de mudas de pimenteira Dedo-de-moça. Revista Ceres, 65:104-109.

Petry C (1999) Plantas ornamentais: aspectos para a produção. Passo Fundo, EDIUPF. 155p.

Saraiva KR, Nascimento RS, Sales FAL, Araújo HF, Fernandes CNV \& Lima AD (2011) Produção de mudas de mamoeiro sob doses de adubação fosfatada utilizando como fonte superfosfato simples. Revista Brasileira de Agricultura Irrigada, 5:376-383.

Silva AC (2014) Reaproveitamento da casca de coco verde. Revista Monografias Ambientais, 13:4077-4086.

Silva ARAD, Bezerra FML, Lacerda CFD, Pereira Filho JV \& Freitas CASD (2013) Trocas gasosas em plantas de girassol submetidas à deficiência hídrica em diferentes estádios fenológicos. Revista Ciência Agronômica, 44:86-93.

Silva, FCS (2009) Manual de análises químicas de solos, plantas e fertilizantes. $2^{\text {nd }}$ ed. Rio de Janeiro, Embrapa Solos. 627p.

Siqueira DP, Barroso DG, Carvalho GCMW, Erthal RM, Rodrigues MCC \& Marciano CR (2019) Lodo de esgoto tratado na composição de substrato para produção de mudas de Plathymenia reticulata Benth. Ciência Florestal, 29:728-739.

Taiz L, Zeiger E, Moller IM \& Murphy A (2017) Fisiologia e Desenvolvimento Vegetal. $6^{\text {th }}$ ed. Porto Alegre, Artmed. 858p.

Torres GN, Camargos SL, Weber OLS, Maas KDB \& Scaramuzza WLMP (2016) Growth and micronutrient concentration in maize plants under nickel and lime applications. Revista Caatinga, 29:796-804. 